UDC 622.279:658.58

\title{
Justification on Choosing Screw Pumping Units as Energy Efficient Artificial Lift Technology
}

\author{
D. I. Sidorkin ${ }^{1)}$, K. S. Kupavykh ${ }^{1)}$ \\ ${ }^{1)}$ Saint-Petersburg Mining University (Saint-Petersburg, Russian Federation) \\ (C) Белорусский национальный технический университет, 2021 \\ Belarusian National Technical University, 2021
}

\begin{abstract}
The paper analyzes the main techniques and technologies of oil fluid recovery in the context of energy consumption, significantly rising over the latest decade. It is recognized that the number of publications in the area of energy efficiency is growing steadily. Currently Russian oil and gas industry are facing the task of accelerating reduction of energy consumption while preserving, or even increasing, production rates. The task is complicated by the fact that the majority of deposits in Russia either have already entered (primarily, Volga-Ural region) or are now entering (West Siberia) their last stage of exploration, whereas new deposits in East Siberia are only being brought into production. Furthermore, a lot of new deposits, which provide for high recovery rates, are profitable a priori as at the first stage of exploration they do not need any artificial lift due to their free flow production without any oil well pumps. However, there is a significant share of new deposits with low-permeability reservoirs, which require either a system of reservoir pressure maintenance or periodic hydraulic fracturing. At the same time deposits at the late stages of exploration, apart from the use of pump units, systems of reservoir pressure maintenance and hydraulic fracturing, require regular repair and restoration, measures against salt and heavy oil sediments, mechanical impurities, flooding, etc., which all has a negative effect on well profitability. In order to solve these problems, the authors review existing methods and calculate specific energy consumption using various pump systems for hypothetical wells, varying in yield. According to the research results, it has been revealed that from the point of view of energy efficiency, it is desirable to equip low- and low-yield wells with sucker rod progressive cavity pump units, medium-yield ones - with electric progressive cavity pumps driven by permanent magnet motor, medium- and high-yield wells - with electric progressive cavity pumps or electric submersible pumps driven by permanent magnet motor, depending on the characteristics of the pumpedout oil fluid.
\end{abstract}

Keywords: pump unit, energy efficiency, submersible electric motor, permanent magnet motor, low-yield well, medium-yield well, energy consumption, water cut oil, hard-to-recover reserves

For citation: Sidorkin D. I., Kupavykh K. S. (2021) Justification on Choosing Screw Pumping Units as Energy Efficient Artificial Lift Technology. Energetika. Proc. CIS Higher Educ. Inst. and Power Eng. Assoc. 64 (2), 143-151. https://doi.org/10.21122/1029-7448-2021-64-2-143-151

Адрес для переписки

Сидоркин Дмитрий Иванович

Санкт-Петербургский горный университет

Васильевский остров, 21 линия, 2,

199106, г. Санкт-Петербург, Российская Федерация

Тел.: +7 812 328-82-00

Sidorkin_DI@pers.spmi.ru
Address for correspondence

Sidorkin Dmitry I.

Saint-Petersburg Mining University

2, $21^{\text {st }}$ Line, Vasilievsky Ostrov,

199106, Saint-Petersburg, Russian Federation

Tel.: +7 812 328-82-00

Sidorkin_DI@pers.spmi.ru 


\title{
Обоснование выбора винтовых насосных установок как энергоэффективной технологии механизированной добычи
}

\author{
Д. И. Сидоркин ${ }^{1)}$, К. С. Купавых ${ }^{1)}$ \\ ${ }^{1)}$ Санкт-Петербургский горный университет (Санкт-Петербург, Российская Федерация)
}

Реферат. В статье проанализированы основные техники и технологии добычи нефтяного флюида в условиях значительного роста цен на электроэнергию за последнее десятилетие. Отмечен стабильный рост публикаций по теме энергоэффективности. Для российской нефтегазодобывающей промышленности актуальна задача снижения энегозатрат при сохранении или даже увеличении темпов производства. Она осложняется тем, что большинство месторождений либо уже вступило (Волго-Уральский регион), либо вступает (Западная Сибирь) в последнюю стадию разработки, тогда как новые месторождения Восточной Сибири еще только вводятся в эксплуатацию. Кроме того, многие новые месторождения, обеспечивающие высокий дебет, рентабельны априори, на первом этапе эксплуатации не требуют механизации, поскольку разрабатываются фонтанным способом, без использования скважинных насосных установок. Но при этом немало и новых месторождений с низкопроницаемыми коллекторами, на которые необходимо воздействовать системой поддержания пластового давления либо проведением периодически гидравлического разрыва пласта. На месторождениях поздней стадии разработки необходимо регулярно осуществлять ремонтно-восстановительные работы, вести борьбу с отложениями солей, асфальтосмолопарафинов, механическими примесями, обводнением и пр., что негативно сказывается на рентабельности скважин. Для решения этих задач в статье рассмотрены существующие методики и проведены расчеты удельных энергозатрат при использовании различных насосных установок для условных скважин, отличающихся дебитом. По результатам исследований выявлено, что с точки зрения энергоэффективности низко- и малодебитные скважины желательно оснащать штанговыми винтовыми насосными установками, среднедебитные - электровинтовыми с вентильными двигателями, средне- и высокодебитные - электровинтовыми или электроцентробежными в зависимости от характеристик выкачиваемого нефтяного флюида.

Ключевые слова: насосная установка, энегетическая эффективность, погружной электический двигатель, вентильный двигатель, низкодебитная скважина, среднедебитная скважина, энергетические затраты, обводненная нефть, трудноизвлекаемые запасы

Для цитирования: Сидоркин, Д. И. Обоснование выбора винтовых насосных установок как энергоэффективной технологии механизированной добычи / Д. И. Сидоркин, К. С. Купавых // Энергетика. Изв. высш. учеб. заведений и энерг. объединений СНГ. 2021. T. 64, № 2. C. 143-151. https://doi.org/10.21122/1029-7448-2021-64-2-143-151

\section{Introduction}

The last decade is characterized by a spike of interest in energy efficient technologies [1-5], which is reflected in the publication activity according to the data from the scientific electronic library (www.elibrary.ru), presented in Fig. 1. Ultimately, it can be explained by the motivation of the industry to reduce specific energy consumption due to a significant increase in electricity rates (according to Fig. 2, within 12 years from 2008 to 2020 they increased by a factor of 3.57) and, as a result, due to rising production costs. 


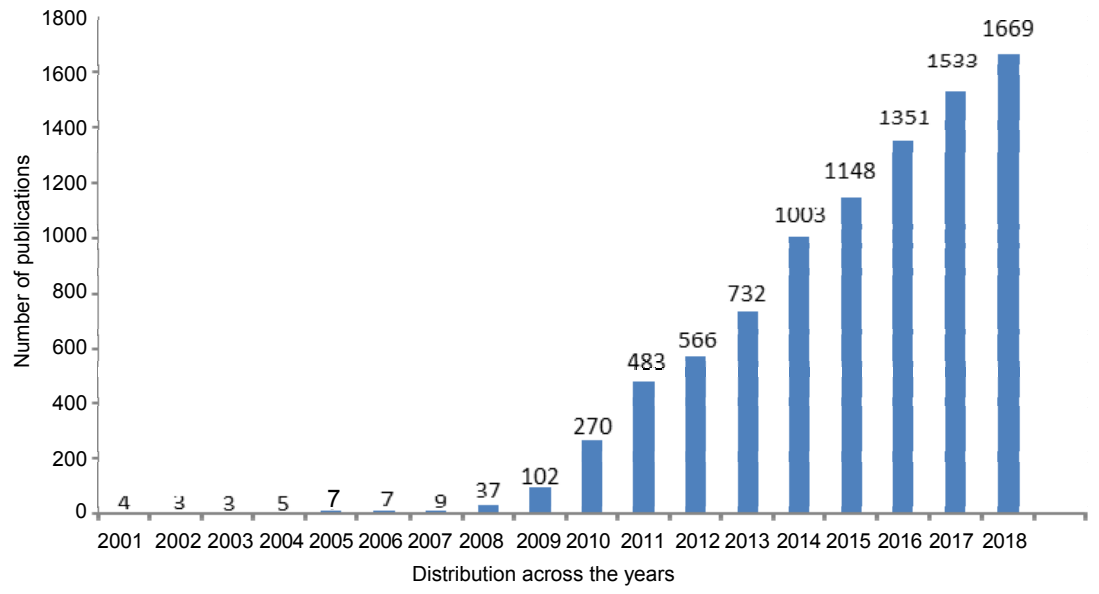

Fig. 1. Analysis of publication activity using keyword "energy efficiency"

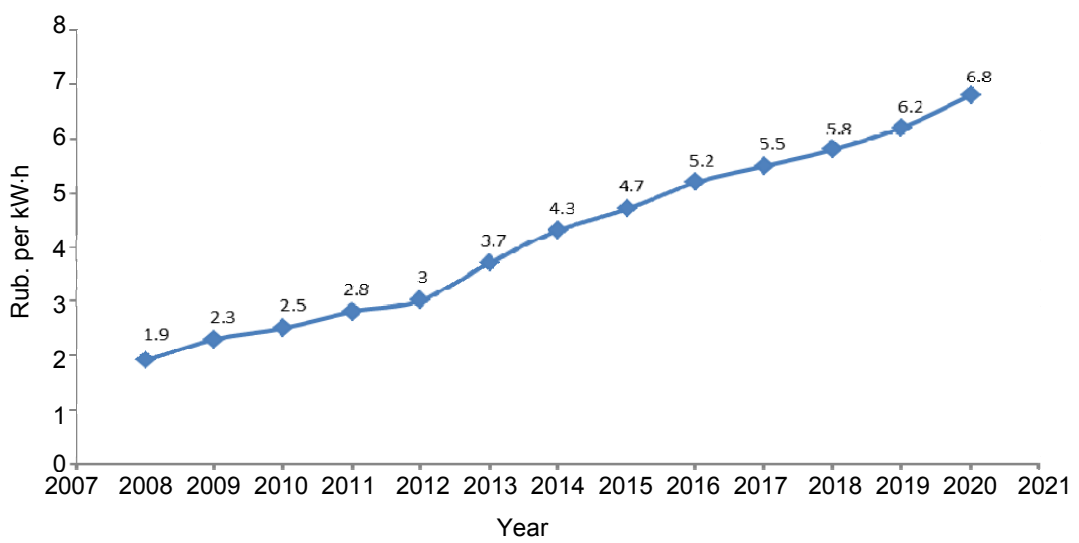

Fig. 2. Electricity rates

Although in general issues of rational consumption of energy and other resources in the process of oil and gas recovery never lose their topicality, since 2008 they have become particularly acute. This was clearly demonstrated by the global oil crisis of 2020, when for many oil producing companies (especially in Russia and in the US) the cost of oil barrel exceeded its contract prices. With this in mind, nowadays Russian oil and gas producing companies need to accelerate the reduction of energy consumption while preserving, or even increasing, production rates.

The task is complicated by the fact that the majority of deposits in Russia either have already entered (primarily, Volga-Ural region) or are now entering (West Siberia) their last stage of exploration, whereas new deposits in East Siberia are only being brought into production. Furthermore, a lot of new deposits, which provide for high recovery rates, are profitable a priori as at the first stage of exploration they do not need any artificial lift due to their free flow production without any oil well pumps. However, there is a significant share of new deposits with low-permeability reservoirs [6], which require either 
a system of reservoir pressure maintenance (RPM) or periodic hydraulic fracturing (HF). At the same time deposits at the late stages of exploration, apart from the use of pump units, RPM systems and HF, require regular repair and restoration, measures against salt and heavy oil sediments, mechanical impurities, flooding, etc., which all has a negative effect on well profitability [7-17]. For instance, as it is seen from Fig. 3, energy consumption at the stage of oil fluid lift accounts for about half of total energy consumption in the process of oil fluid extraction.
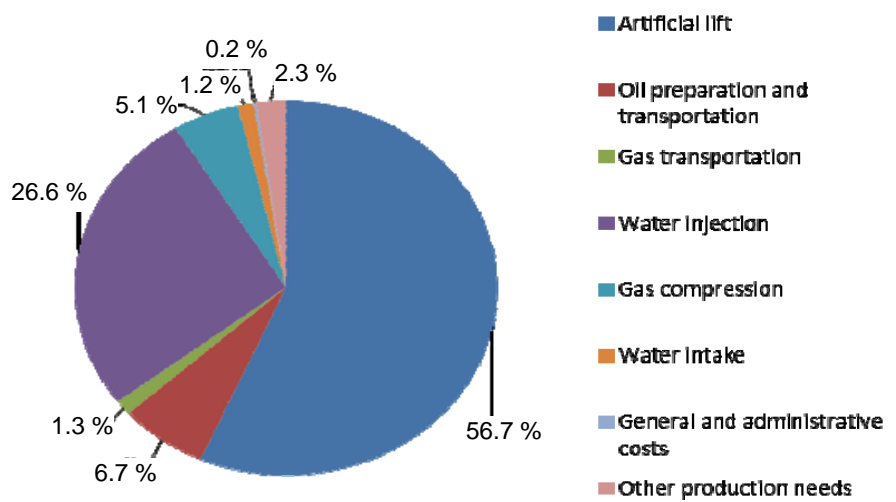

Fig. 3. The structure of energy consumption for $3^{\text {rd }}$ and $4^{\text {th }}$ exploration stages of oil fluid recovery

As follows from Fig. 3, the major share (56.7 \%) in the structure of energy consumption is taken up by the lift of oil fluid from the wells. Hence the best results of energy efficiency improvement can be obtained in this area.

Energy efficiency directly depends on the performance factors of all the elements in a pump unit. Therefore, the higher the performance factor, the greater energy efficiency, i. e. the lower energy consumption of the oil fluid lift.

Currently most operating wells $[18,19]$ are equipped with electric submersible pumps (ESP) - around $66 \%$ (99.457 wells in 2018); then followed by sucker rod pumps (SRP) - around $30 \%$ (45.571 wells in 2018); other equipment (screw and diaphragm pumps, ejectors, gas lifts, hydraulic pulsers etc.) account for approximately $4 \%$. From the position of energy efficiency and production potential, the most promising equipment is progressive cavity pumps (either driven by submersible electric motor or using a sucker rod drive). In 2018 they were utilized approximately in 1.600 wells. And their number is rising every year due to the necessity to lift heavy viscous oil and the growing number of wells classified as low-yield.

Let us assembly-by-assembly consider energy losses for four types of pump units, viz. ESP, SRP, electric progressive cavity pumps (EPCP) and sucker rod progressive cavity pumps (SRPCP).

The structure of losses will be identical for ESP and EPCP systems, as the only difference between them is in the pump design. It should also be noted that the efficiency factor of ESP systems varies in a wide range depending on the necessary feed - from $25 \%$ at $15 \mathrm{~m}^{3} /$ day yield to $68 \%$ at $700 \mathrm{~m}^{3} /$ day yield, 
which leads to high specific energy consumption. The impact of feed on EPCP efficiency factor is not that significant.

$$
P_{E S P / E P C P}=P_{u c}+\Delta P_{e f}+\Delta P_{l d u}+\Delta P_{p r}+\Delta P_{s e m}+\Delta P_{c l}+\Delta P_{t r}+\Delta P_{c s}+\Delta P_{g s}+\Delta P_{i f},
$$

where $P_{u c}$ - useful capacity of the pump; $\Delta P_{e f}$ - power losses, defined by the efficiency factor; $\Delta P_{l d u}$ - power losses in the letdown unit; $\Delta P_{p r}$ - losses in the protector; $\Delta P_{\text {sem }}$ - losses in the submersible electric motor; $\Delta P_{c l}$ - losses in the cable line; $\Delta P_{t r}$ - losses in the transformer; $\Delta P_{c s}-$ losses at the control station; $\Delta P_{g s}-$ losses in the group socket; $\Delta P_{i f}-$ losses in the inlet filter [20-26].

Calculation of SRP energy consumption is complicated by the system's constant time variation, associated with the recurring pumping cycle; still a general expression can be defined as follows [27]:

$$
P_{S R P}=P_{u c}+\Delta P_{c s}+\Delta P_{e m}+\Delta P_{r e d}+\Delta P_{p j}+\Delta P_{S R P},
$$

where $\Delta P_{e m}-$ losses in the electric motor; $\Delta P_{\text {red }}$ - losses in the reduction gear; $\Delta P_{p j}$ - losses in the pumpjack; $\Delta P_{S R P}-$ power losses in the pump.

Power losses of the SRPCP system depend primarily on the characteristics of oil fluid and the presence of mechanical impurities [28, 29]

$$
P_{S R P C P}=P_{u c}+\Delta P_{c s}+\Delta P_{e m}+\Delta P_{r e d}+\Delta P_{r s}+\Delta P_{P C P},
$$

where $\Delta P_{r s}$ - losses from the rotation of rod string in the fluid and friction on the inner tubing wall; $\Delta P_{P C P}-$ power losses in the pump.

Let us compare calculations of specific energy consumption for the above mentioned pump units depending on specific well conditions.

Specific energy consumption is estimated using the following formula:

$$
P_{s p . v o l}=\frac{P}{Q_{h} T},
$$

where $P$ - energy from the grid, $\mathrm{kW} \cdot \mathrm{h} ; Q_{h}-$ hourly volumetric yield, $\mathrm{m}^{3} / \mathrm{h}$; $T$ - time, $\mathrm{h}$.

The following main parameters, presented in Tab. 1, were selected as conditions. It should be noted that the values of these parameters are hypothetical and are assigned solely for the purpose of comparative calculations.

Table 1

Parameters of compared wells

\begin{tabular}{|l|c|c|c|}
\hline \multirow{2}{*}{\multicolumn{1}{c|}{ Parameter }} & \multicolumn{3}{c|}{ Well scenario } \\
\cline { 2 - 4 } & 1 & 2 & 3 \\
\hline Yield & 15 & 50 & 100 \\
\hline Pump setting depth & 1.100 & 1.100 & 1.100 \\
\hline Oil fluid density (oil + water) & 950 & 950 & 950 \\
\hline Oil fluid viscosity, Pa·s & 2.2 & 2.2 & 2.2 \\
\hline
\end{tabular}

After assigning the parameters, comparative calculations of consumed energy and specific energy consumption were calculated for each well scenario using the methods described above. Calculation results are presented in Tab. 2. 
Calculation results of specific volumetric energy consumption for different types of pump units, $\mathrm{kW} \cdot \mathbf{h} / \mathrm{m}^{3}$

\begin{tabular}{|c|c|c|c|c|}
\hline No & $\begin{array}{c}\text { Electric } \\
\text { submersible pump } \\
\text { unit (SEM/PMM) }\end{array}$ & $\begin{array}{c}\text { Sucker rod } \\
\text { pump unit }\end{array}$ & $\begin{array}{c}\text { Electric progressive } \\
\text { cavity pump unit } \\
\text { (SEM/PMM) }\end{array}$ & $\begin{array}{c}\text { Sucker rod } \\
\text { progressive cavity } \\
\text { pump unit }\end{array}$ \\
\hline 1 & $37.53 / 25.07$ & 17.62 & $28.34 / 15.40$ & 9.05 \\
\hline 2 & $11.62 / 9.84$ & 7.35 & $8.89 / 6.54$ & 7.70 \\
\hline 3 & $7.21 / 6.49$ & - & $5.58 / 4.48$ & 7.47 \\
\hline
\end{tabular}

As it is seen from the calculation of specific volumetric energy consumption (Tab. 2, Fig. 4), there is a significant difference between pump units. Reliability of calculation results is confirmed by practical measurements from the wells, presented by V. I. Tarasov, M. N. Kaverin, S. B. Yakimov in paper [17].

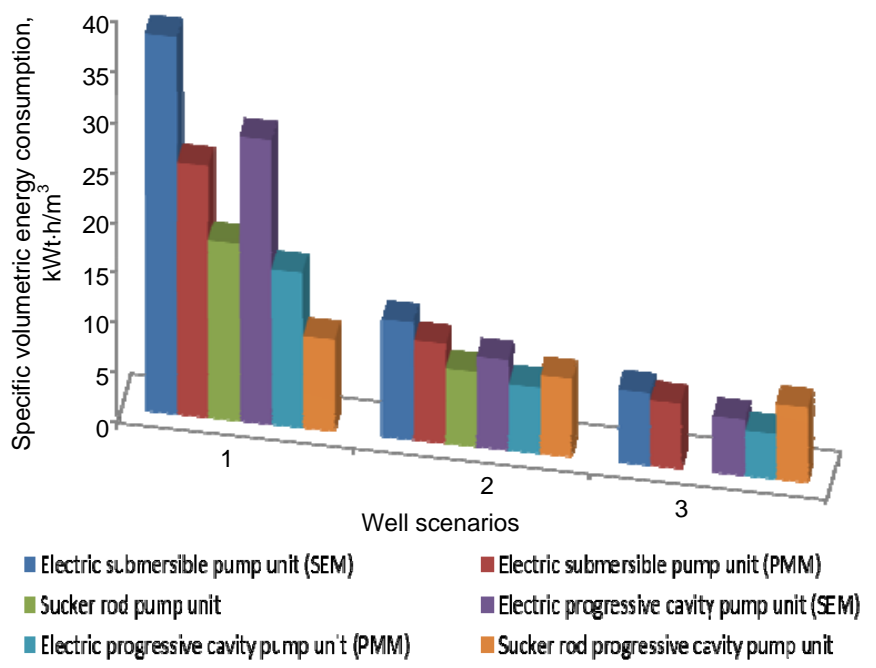

Fig. 4. Calculation results of specific volumetric energy consumption for different types of pump units

ESP systems are characterized by maximum energy consumption $\left(37.53 / 25.07 \mathrm{~kW} \cdot \mathrm{h} / \mathrm{m}^{3}\right)$ in the process of low-yield $\left(15 \mathrm{~m}^{3} /\right.$ day $)$ well exploration; with an increase in the volume of pumped fluid it drops significantly. This is explained by the fact that ESP efficiency factor varies in a wide range, from 15 to $70 \%$ depending on the typical size, reaching the maximum at $700-800 \mathrm{~m}^{3} /$ day, as shown in paper [30]. It implies that this type of systems is optimal for high-yield wells (over $50 \mathrm{~m}^{3} /$ day). At the same time even the application of state-of-the-art permanent magnet motors (PMM) brings no significant changes to the overall picture, providing an economy of $33.03 \%$ under the first scenario, $15.32 \%$ under the second one and $9.08 \%$ under the third one, but still demonstrating a high level of energy consumption compared to other pump systems. The effect at low-yield fields can be increased with the use of small energy efficient ESP units $(2 \mathrm{~A}, 3)$, but all their advantages are derailed by high costs of the equipment, which prolong the payback period by several years.

The application of SRP units produces a much better effect than introduction of PMM: $53.03 \%$ under the first scenario and $36.75 \%$ under the second one. The third scenario was not calculated, as it cannot be implemented at oil wells 
producing more than $50 \mathrm{~m}^{3} /$ day due to strict design limitations of the pump unit. It should be noted that the calculations imply the use of a conventional pumpjack as a top drive, which does not lead to optimal energy efficiency parameters. The use of chain drives (CD) or hydraulic drives of "Geyser" or "Ob" types provides an economy of about $20 \%$, but the problems, associated with operating costs (CD) or climate (hydraulic drive), put restrictions on their wide application.

The assembly itself is practically identical for ESP and EPCP units, but there is a basic distinction in the principle of pump operation, therefore pumps driven by SEM and PMM are to be compared separately. Analysis shows that, in case of SEM use, EPCP is more energy efficient than ESP - by $24.48 \%$ under the first scenario, by $23.43 \%$ under the second one and by $22.61 \%$ under the third one. Comparison of PMM-driven pump units produced the results of $38.57 \%$ for the first scenario, $33.56 \%$ for the second one and $30.97 \%$ for the third one. It is clear that energy efficiency of EPCP is higher than that of ESP, both for SEM and PMM, but a large-scale replacement does not seem feasible due to technological limitations.

It is evident that in terms of energy efficiency SRPCP is practically unrivaled among the pump units suitable for low-yield wells (Tab. 3). In case of yield over $50 \mathrm{~m}^{3} /$ day (scenario 2), the situation is not that straightforward, but SRP is rarely if ever used under such conditions, and EPCP is quite expensive, so it is easier and cheaper to install SRPCP. In case of $100 \mathrm{~m}^{3} /$ day (scenario 3) the calculations reveal negative comparative energy efficiency.

Table 3

Comparison of SRPCP to other pump systems in terms of specific energy consumption (on a percentage basis)

\begin{tabular}{|c|c|c|c|c|c|}
\hline No & $\begin{array}{c}\text { Electric } \\
\text { submersible pump } \\
\text { unit (SEM) }\end{array}$ & $\begin{array}{c}\text { Electric } \\
\text { submersible pump } \\
\text { unit (PMM) }\end{array}$ & $\begin{array}{c}\text { Sucker rod } \\
\text { pump unit }\end{array}$ & $\begin{array}{c}\text { Electric } \\
\text { progressive cavity } \\
\text { pump (SEM) }\end{array}$ & $\begin{array}{c}\text { Electric } \\
\text { progressive cavity } \\
\text { pump (PMM) }\end{array}$ \\
\hline 1 & 75.89 & 63.90 & 48.64 & 68.07 & 41.23 \\
\hline 2 & 33.73 & 21.75 & -4.76 & 13.39 & -17.74 \\
\hline 3 & -3.61 & -15.10 & - & -33.87 & -66.74 \\
\hline
\end{tabular}

In Russia progressive cavity pumps (with both submersible and sucker rod drives) are not yet widely used despite their apparent advantages, especially from the viewpoint of energy efficiency in the wells, producing less than $50 \mathrm{~m}^{3} /$ day.

SRPCP does not have many drawbacks, but they are quite significant:

1) a stator elastomer in PCP units gets quickly destroyed when oil fluid contains $\mathrm{CO}_{2}$ and $\mathrm{H}_{2} \mathrm{~S}$, it swells from the water and wears off by rubbing with mechanical particles. Nowadays there is quite a diversity of rubber stocks for every type of problem, i. e. a competent choice is required to select the material of stator insert. Abroad such universal materials as UltraFlex-157, hydrogenated high-nitrile soft (HHNS) and high-nitrile hard $(\mathrm{HNH})$ elastomers are widely used. Besides, full-steel rotor/stator couples and twin screw pumps (similar to multiphase pumps) come into operation;

2) restrictions regarding the depth of pump suspension, caused by the durability of the rod string. Unfortunately, Russia does not produce sucker rods that can resist high-torque load. Hence, there is the limit of $1.000-1.200 \mathrm{~m}$. 
At the same time it is understood that foreign SRPCP systems can go $3.000 \mathrm{~m}$ down the hole and lower.

Advantages are more numerous: independence of the pressure head from rotor speed; high absorbing capacity; absence of valves; uniform rate of injection; low quantities of metal in the pump design.

With this in mind, the major advantage of SRPCP (same as EPCP) is the possibility to lift viscous heavy bitumen oil.

In 1990s Russia actively introduced SRPCP systems, of both domestic and foreign production, but due to unsatisfactory selection of rotor/stator couples, their tightness, rod string assembly their implementation was practically cancelled.

\section{CONCLUSION}

To sum it up, the following conclusions can be drawn from the position of energy efficiency: low-yield wells need to be equipped with sucker rod progressive cavity pumps; low- and middle-yield wells require electric progressive cavity pumps, driven by permanent magnet motor; for middle- and high-yield wells the best fit is either electric progressive cavity pumps or electric submersible pumps, driven by permanent magnet motor, depending on the oil fluid.

\section{REFERENCES}

1. Belsky A. A., Dobush V. S. (2017) Autonomous Electrothermal Facility for Oil Recovery Intensification Fed by Wind Driven Power Unit. IOP Conference Series: Earth and Environmental Science, 87 (3), 032006. https://doi.org/10.1088/1755-1315/87/3/032006.

2. Galyautdinov I. M., Krasnov O. S. (2016) Assessment Potential of Oil Fields Being in the Late Stage of Enhanced Energy Efficiency. Neftegazovaya Geologiya - Teoriya i Praktika = Petroleum Geology - Theoretical and Applied Studies, 11 (1), 1-18. https://doi.org/10.17353/20705379/7 2016 (in Russian).

3. Abildinova S. K., Musabekov R. A., Rasmukhametova A. S., Chicherin S. V. (2019) Evaluation of the Energy Efficiency of the Stage Compression Heat Pump Cycle. Energetika. Izvestiya Vysshikh Uchebnykh Zavedenii $i$ Energeticheskikh Ob'edinenii SNG = Energetika. Proceedings of the CIS Higher Education Institutions and Power Engineering Associations, 62 (3), 293-302. https://doi.org/10.21122/1029-7448-2019-62-3-293-302 (in Russian).

4. Panevnyk D. A., Panevnyk A. V. (2020) Improving the Energy Efficiency of the Use of Borehole Jet Pumps. Energetika. Izvestiya Vysshikh Uchebnykh Zavedenii i Energeticheskikh Ob'edinenii $S N G=$ Energetika. Proceedings of the CIS Higher Education Institutions and Power Engineering Associations, 63 (5), 462-471. https://doi.org/10.21122/1029-7448-202063-5-462-471 (in Russian).

5. Dmitriev A. A., Gerasimov V. E. (2020) To the Issue of Complex Increasing Energy Efficiency of Electric Receivers of Oil and Gas Fields. IOP Conference Series: Earth and Environmental Science, 421 (7), 072009. https://doi.org/10.1088/1755-1315/421/7/072009.

6. Gasumov R. A. (2018) Causes of Fluid Entry Absence when Developing Wells of Small Deposits (on the Example of Khadum-Batalpashinsky Horizon). Zapiski Gornogo Instituta = Journal of Mining Institute, 234, 630-636. https://doi.org/10.31897/PMI.2018.6.630 (in Russian).

7. Kreidenko T. F., Chernyaev M. V., Grigoreva E. M., Korenevskaya A. V. (2018) Enhancing the Energy Efficiency of Oil and Gas Companies as a Factor of their Sustainable Development. AD ALTA: Journal of Interdisciplinary Research, 8 (1S4), 176-182.

8. Belsky A. A., Korolyov I. A. (2018) Thermal Oil Recovery Method Using Self-Contained Windelectric Sets. Journal of Physics: Conference Series, 1015 (5), 052001. https://doi.org/10. 1088/1742-6596/1015/5/052001.

9. Zyrin V. O., Vasiliev B. U. (2016) Designing the Electrothermal Complex Control System for Enhanced Oil Recovery. International Journal of Applied Engineering Research, 10 (24), 44183-44188.

10. Zyrin V. O. (2018) Electrothermal Complex for Heavy Oil Recovery: Analysis of Operating Parameters. International Journal of Mechanical Engineering and Technology, 9 (11), 1952-1961. 
11. Kuzovkin A. I. (2018) Energy Prices and Energy Efficiency. Mikroekonomika = Microeconomics, (5), 78-81 (in Russian).

12. Zakirov D. G., Mukhamedshin M. A., Zakirov G. D., Fayzrakhmanov R. A., Nikolaev A. N., Ryumkin A. A. (2019) Problems and Ways to Improve Energy Efficiency, Environmental Performance and Energy Consumption of Oil Mining. Neftyanoe Khozyaystvo = Oil Industry, (10), 90-93 (in Russian)

13. Golubev I. A., Suprun I. K. Application of Magnetic Units for Intensification of Water Treatment. IOP Conference Series: Materials Science and Engineering, 862, 062051. https://doi. org/10.1088/1757-899X/862/6/062051.

14. Verisokin A. E., Serdyukov D. Yu., Vasil'yev V. A., Gun'kina T. A., Shesterikova R. E. (2020) Simulation of Proppantflowback from Hydraulic Fractures. IOP Conference Series: Materials Science and Engineering, 860, 012001. https://doi.org/10.1088/1757-899X/860/1/012001.

15. Verisokin A. E., Vasil'yev V. A., Gun'kina T. A. (2019) Packer Design Research Used in Hydraulic Fracturing. IOP Conference Series: Earth and Environmental Science, 378 (1), 012106. https://doi.org/10.1088/1755-1315/378/1/012106.

16. Belsky A. A., Dobush V. S., Morenov V. A., Sandyga M. S. (2018) The Use of a Wind-Driven Power Unit for Supplying the Heating Cable Assembly of an Oil Well, Complicated by the Formation of Asphalt-Resin-Paraffin Deposits. Journal of Physics: Conference Series, 1111 (1), 1-7. https://doi.org/10.1088/1742-6596/1111/1/012052.

17. Tarasov V. I., Kaverin M. N., Yakimov S. B. (2014) Comparison of Energy Consumption for Different Artificial Lift Methods at JSC "Rosneft". Nauchno-Tekhnicheskii Vestnik $O A O$ "NK "Rosneft" [Scientific and Technical Bulletin of JCS "Rosneft"], (3), 5-11 (in Russian).

18. Masakov I. D. (ed.) (2019) Industrial Production in Russia: Statistical Digest. Moscow, Rosstat Publ. 286 (in Russian).

19. Kamaletdinov R. (2018) Major Trends in Artificial Lift in Russia. Advisory Board on Mechanized Oil Extraction. Oil \& Gas Journal Russia, (6-7). Available at: http://pump-sovet.com/upload/ statya_kamaletdinov_oil\&gas journal_\%E2\%84\%966-7_2018.pdf. (Accessed 22.09.2020) (in Russian).

20. Hakimyanov M. I., Shafikov I. N. (2013) Analysis of Energy Consumption in the Process of Artificial Oil Lift Using Electric Submersible Pumps. Elektrotekhnicheskie i Informatsionnye Kompleksy $i$ Sistemy = Electrical and Data Processing Facilities and Systems, 9 (3), 37-41 (in Russian).

21. Ginzburg M. Ya., Pavlenko V. I., Klimov V. P. (2010) On ESP Energy Parameters. Inzhenernaya Praktika [Engineering Practice], (8), 12-16 (in Russian).

22. Kozlova L. P., Belov A. M., Kozlova O. A. (2020) Improving the Energy Efficiency of the Electric Drive of the Pumping Equipment. IEEE. Conference of Russian Young Researchers in Electrical and Electronic Engineering (EIConRus). https://doi.org/10.1109/eiconrus49466.2020.9039408.

23. Sagdatullin A. M. (2014) Analysis and Synthesis of the Structure of the Pump Electric Drive Control System of Oil Treatment Process. Izvestiya Vysshikh Uchebnykh Zavedenii. Neft' $i \mathrm{Gaz}=$ Proceedings of the CIS Higher Education Institutions Oil and Gas Studies, (6), 106-112 (in Russian).

24. Sukhanov A., Gansheng Y., Jichao Y., Perelman O., Derkach N. (2018) Enhancement of Electric Submersible Pump Energy Efficiency by Replacing an Inductive Motor with a Permanent Magnet Motor. Oil Gas European Magazine, 44 (3), 146-150.

25. Khakimyanov M. I., Shafikov I. N., Khusainov F. F. (2016) Electric Submersible Pumps in Oil Production and their Efficiency Analysis. Proc. of the $4^{\text {th }}$ International Conference on Applied Innovations in IT, (ICAIIT), 35-38.

26. Kovalchuk M. S., Poddubniy D. A. (2018) Diagnosis of Electric Submersible Centrifugal Pump. IOP Conference Series: Earth and Environmental Science, (115), 012026. https://doi. org/10.1088/1755-1315/115/1/012026.

27. Hakimyanov M. I. (2014) Specific Energy Consumption in the Process of Artificial Oil Lift Using Downhole Sucker Rod Pumps. Vestnik Ufimskogo Gosudarstvennogo Aviatsionnogo Tekhnicheskogo Universiteta = Vestnik USATU, 2 (63), 54-60 (in Russian).

28. Sultanov B. Z., Sidorkin D. I. (2004) Power Demands of Tophead Progressive Cavity Pump Unit. Tekhnologii Toplivno-Energeticheskogo Kompleksa [Technologies of Fuel \& Energy Complex], (3), 31-34 (in Russian).

29. Urazakov K. R., Latypov B. M., Ismagilov R. R. (2015) Methodology for Calculating Sucker Rod Strings of Progressive Cavity Pumps. Neftegazovoe Delo = Oil \& Gas Business, (4). Available at: http://ogbus.ru/files/ogbus/issues/4_2015/ogbus_4_2015_p72-94_UrazakovKR_ ru.pdf (in Russian).

30. Kaverin M. N., Kuryaev S. V. (2014) The Method of Planning and Analysis of Energy Efficiency in Oil Production. Nauchno-Tekhnicheskii Vestnik OAO "NK "Rosneft" [Scientific and Technical Bulletin of JCS "Rosneft"], (3), 12-17 (in Russian).

Received: 11 November 2020 Accepted: 19 January $2021 \quad$ Published online: 30 March 2021 